\title{
Betamethasone Versus Ketamine for Attenuation of POST in Patients Undergoing Surgeries Under GA with Endotracheal Intubation- A Clinical Study
}

\author{
S. Ankalagowri Sankardevar ${ }^{\circledR 1}$, N R Arjun ${ }^{\circledR 2}$, Uthkala B Hegde ${ }^{\circledR 3}$ \\ ${ }^{1}$ Consultant, Dr. Sheshaiah's Prajavaidyashala Hospital, Guntur, Andhra Pradesh, India, ${ }^{2}$ Assistant Professor, Department of Critical Care Medicine, Kasturba Medical \\ College and Hospital, Manipal, Karnataka, India, 3Professor, Department of Anaesthesiology, MVJ Medical College and Research Hospital, Hoskote, Banglore, India.
}

\section{Abstract}

Background: Postoperative sore throat is one of the most common complications after endotracheal intubation. The present study was conducted to assess the role of betamethasone gel applied over the endotracheal tube cuff for attenuation of POST in patients undergoing surgeries under GA with endotracheal intubation and compare it with ketamine nebulization. Subjects and Methods : This is a randomized controlled prospective study conducted in 90 patients of either sex between 18-70 years of age divided into three groups. Group I patients received ketamine 50 mg, group II received $3 \mathrm{ml}$ of water soluble $0.05 \%$ betamethasone gel, group III received $3 \mathrm{ml}$ of water soluble $2 \%$ lignocaine. POST was graded on a four-point scale ( $0-3) ; 0=$ no sore throat; $1=$ mild sore throat (complains of sore throat only on questioning); $2=$ moderate sore throat (complains of sore throat on his/her own); $3=$ severe sore throat (change of voice or hoarseness, associated with severe throat pain). Results: The mean duration of surgery in group I was 128.5 minutes, in group II was 131 minutes and in group III was 134.5 minutes. There were 6 (20\%), 7 (23.3) and $14(46.6 \%)$ cases in group I, II and III respectively. The difference was significant $(\mathrm{P}<0.05)$. At 0 hour there were 3 cases in group I, II and 10 in group III, at 2 hours was 3, 5 and 12 in group I, II and III respectively, at 6 hours was 5,4 and 14 cases in group I, II and III respectively, at 12 hours was 3, 3 and 12 cases in group I, II and III respectively and at 24 hours was 2, 2 and 12 cases in group I, II and III respectively. Conclusion: Authors found that POST can be equally managed with nebulisation with ketamine preoperatively and application of betamethasone gel over endotracheal tube cuff.

Keywords: Betamethasone, Ketamine, Nebulisation

Corresponding Author: Uthkala B Hegde, Professor, Department of Anaesthesiology, MVJ Medical College and Research Hospital, Hoskote, Banglore, India.

E-mail: ubshetty8@gmail.com

Received: 02 July 2020

Revised: 05 August 2020

Accepted: 14 August 2020

Published: 16 December 2020

\section{Introduction}

Post-operative sore throat (POST) occurs in 21-65\% of patients receiving general anaesthesia (GA) with tracheal intubation. Though considered as a minor complication, but it may cause significant post-operative morbidity and patient dissatisfaction. ${ }^{[1]}$ Various non-pharmacological and pharmacological trials have been used for attenuating POST with no proven single modality. ${ }^{[2]}$

Postoperative sore throat is one of the most common complications after endotracheal intubation, which usually lingers for 12-24 hours after the operation. The incidence is estimated to be of $18-65 \%$ in different studies. Factors contributing to development of POST include trauma to pharyngolaryngeal mucosa from laryngoscopy, placement of nasogastric tube or oral suctioning. ${ }^{[3]}$ The cuff design and pressure may affect tracheal mucosal capillary perfusion. Contact of tracheal tube with vocal cords and posterior pharyngeal wall result in edema and mucosal lesion. The common prophylactic measures used to decrease the incidence of POST include the use of smaller-sized endotracheal tubes with a low intracuff pressure. ${ }^{[4]}$

The pharmacological methods used to reduce POST include use of beclomethasone gel, gargling with azulene sulphonate, ketamine and licorice. Ketamine is an N-methyl-D-aspartate (NMDA) receptor antagonist and has been used as a gargle for reducing the incidence and severity of POST due to its anti-nociceptive and anti-inflammatory effects. ${ }^{[5]}$ Ketamine nebulization has a few advantages over gargle: It spares the patient from the bitter taste of ketamine, much smaller 
volume is required as opposed to larger volumes required for gargle with risk of aspiration if accidentally swallowed. ${ }^{[6]}$ The present study was conducted to assess the role of betamethasone gel applied over the endotracheal tube cuff for attenuation of POST in patients undergoing surgeries under GA with endotracheal intubation and compare it with ketamine nebulization.

\section{Subjects and Methods}

This is a randomized controlled prospective study conducted in 90 patients of either sex between 18-70 years of age divided into three groups. The study was undertaken at the hospital attached to PES institute of Medical sciences and Research, Andhra Pradesh.

General physical examination was done in all. Group I patients received ketamine $50 \mathrm{mg}(1.0 \mathrm{ml})$ along with $4.0 \mathrm{ml}$ of normal saline nebulization for $15 \mathrm{~min}$ via nebulization mask connected to wall mounted oxygen driven source at the rate of $8 \mathrm{lit} / \mathrm{min}$, $25 \mathrm{~min}$ before surgery. Group II received $3 \mathrm{ml}$ of water soluble $0.05 \%$ betamethasone gel applied over endotracheal tubes cuff. Group III received $3 \mathrm{ml}$ of water soluble $2 \%$ lignocaine jelly applied over endotracheal tube cuff, taken as control.

Sore throat assessment and hemodynamic recording was done at pre-nebulization (baseline parameters before nebulization of patient), pre-induction (parameters after nebulization and just before induction of GA), immediately after extubation ( 0 h), 2, 6, 12 and $24 \mathrm{~h}$ post-operatively. POST was graded on a four-point scale $(0-3) ; 0=$ no sore throat; $1=$ mild sore throat (complains of sore throat only on questioning); $2=$ moderate sore throat (complains of sore throat on his/her own); $3=$ severe sore throat (change of voice or hoarseness, associated with severe throat pain). Results were statistically analyzed.

\section{Results}

Table 1: Distribution of groups

\begin{tabular}{llll}
\hline Groups & Group I & Group II & Group III \\
\hline Agent & Ketamine & $\begin{array}{l}\text { Betamethason } \\
\text { gel }\end{array}$ & Lignocaine \\
\hline Number & 30 & 30 & 30 \\
\hline
\end{tabular}

[Table 1] shows distribution of patients in different groups.

\begin{tabular}{|llllll}
\hline \multicolumn{2}{|c|}{ Table 2: Duration of surgery } & & & & \\
\hline Groups & Group I & Group II & \multicolumn{2}{l|}{ Group III } \\
\hline Mean & 128.5 & \pm & $131 \pm 24.29$ & 134.5 & \pm \\
& 26.9 & & & 23.64 & \\
\hline
\end{tabular}

[Table 2] shows that mean duration of surgery in group I was 128.5 minutes, in group II was 131 minutes and in group III was 134.5 minutes.

\begin{tabular}{lllll}
\hline \multicolumn{5}{l}{ Table 3: Incidence of POST in groups } \\
\hline Groups & Group I & $\begin{array}{l}\text { Group } \\
\text { II }\end{array}$ & $\begin{array}{l}\text { Group } \\
\text { III }\end{array}$ & P value \\
$\begin{array}{l}\text { Number } \\
(\%)\end{array}$ & $6(20 \%)$ & $7(23.3)$ & 14 & 0.01 \\
\hline
\end{tabular}

[Table 3] shows that there were $6(20 \%), 7(23.3)$ and 14 $(46.6 \%)$ cases in group I, II and III respectively. The difference was significant $(\mathrm{P}<0.05)$.

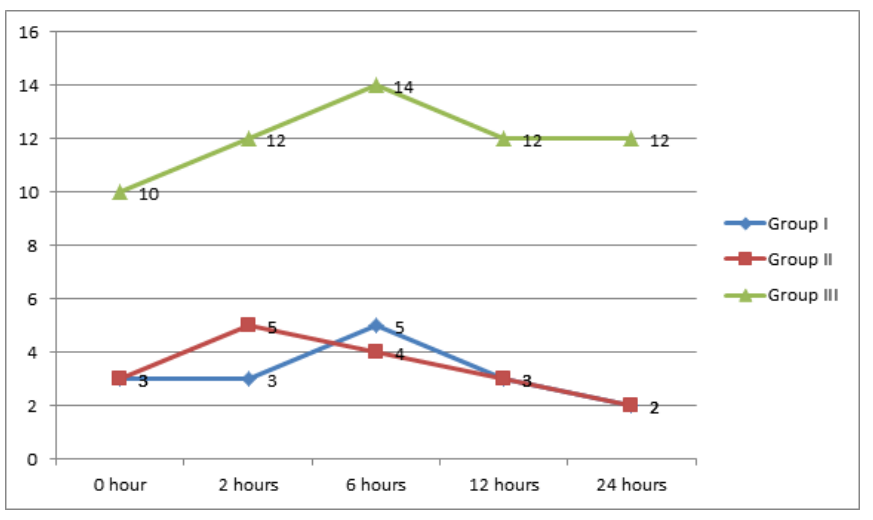

Figure 1: Incidence and severity of POST at different time intervals

[Figure 1] shows that at 0 hour there were 3 cases in group I, II and 10 in group III, at 2 hours was 3, 5 and 12 in group I, II and III respectively, at 6 hours was 5,4 and 14 cases in group I, II and III respectively, at 12 hours was 3, 3 and 12 cases in group I, II and III respectively and at 24 hours was 2, 2 and 12 cases in group I, II and III respectively.

\section{Discussion}

Ketamine is N-methyl daspartate (NMDA) receptor antagonist and has been used as gargle or nebulization. ${ }^{[7]}$ Various preclinical and clinical studies have reported that clonidine produces antinociception regardless of the route of administration (central or peripheral). ${ }^{[8]}$ Topical administration of clonidine elicits antinociception by blocking the emerging pain signals at peripheral terminals through alpha 2 adrenoceptors without producing the undesirable central side effect observed after systemic administration. ${ }^{[9]}$ The present study was conducted to assess the role of betamethasone gel applied over the endotracheal tube cuff for attenuation of POST in patients undergoing surgeries under GA with endotracheal intubation and compare it with ketamine nebulization. 
In present study, patients were divided into 3 groups. Group I patients received ketamine $50 \mathrm{mg}(1.0 \mathrm{ml})$, group II received $0.05 \%$ betamethasone gel and group III received $2 \%$ lignocaine jelly applied over endotracheal tube cuff, taken as control.

Betamethasone gel applied over the endotracheal tube (ETT) and ketamine gargle were found to be comparable in attenuating POST during the first 24 post-operative hours after elective surgical procedures. However, the incidence of postoperative cough and hoarseness of voice was attenuated better with betamethasone application. ${ }^{[10]}$

We found that mean duration of surgery in group I was 128.5 minutes, in group II was 131 minutes and in group III was 134.5 minutes. There were 6 (20\%), 7 (23.3) and 14 (46.6\%) cases in group I, II and III respectively. The difference was significant $(\mathrm{P}<0.05)$.

Ketamine is N-Menthyl daspartate (NMDA) receptor antagonist and has been used as gargle or nebulization. The mechanism of topical effect of ketamine nebulization was due to attenuation of the local inflammation and also due to peripheral analgesic effect of kitamine. The present study was conducted to assess the role of betamethasone gel applied over the endotracheal tube cuff for attenuation of POST in patients undergoing surgeries under GA with endotracheal intubation and compare it with ketamine nebulization. ${ }^{[11]}$

Ahuja et al, ${ }^{[1]}$ included 100 patients belonging to American Society of Anaesthesiologists physical status I-II in the age group 20-60 years, of either sex undergoing surgery under general anaesthesia (GA) were enrolled. Patients were randomised into two groups; group saline (S) received saline nebulisation $5.0 \mathrm{ml}$ and group ketamine $(\mathrm{K})$ received ketamine $50 \mathrm{mg}(1.0 \mathrm{ml})$ with $4.0 \mathrm{ml}$ of saline nebulisation for $15 \mathrm{~min}$. GA was induced 10 min after completion of nebulisation in the patients. The POST and haemodynamic monitoring were done pre-nebulization, pre-induction, on reaching post-anaesthesia care unit, and at 2, 4, 6, 8, 12 and $24 \mathrm{~h}$ post-operatively. POST was graded on a four-point scale (0-3). The overall incidence of POST was 33\%; 23 patients (46\%) in saline and 10 patients $(20 \%)$ in ketamine group experienced POST (Fisher's exact $\mathrm{P}$ $=0.01)$. The use of ketamine nebulization attenuated POST at $2 \mathrm{~h}$ and $4 \mathrm{~h}$ post-operatively $(\mathrm{P}<0.05)$. The primary outcome was incidence of POST at $4 \mathrm{~h} ; 13$ patients in group S versus 4 patients in group $\mathrm{K}(\mathrm{P}=0.03)$ experienced POST at $4 \mathrm{~h}$. The moderate sore throat occurred in 6 patients in group $\mathrm{S}$ and none in group $\mathrm{K}$ at $2 \mathrm{~h}$, post-operatively $(\mathrm{P}=0.02)$.

We found that at 0 hour there were 3 cases in group I, II and 10 in group III, at 2 hours was 3,5 and 12 in group I, II and III respectively, at 6 hours was 5,4 and 14 cases in group I, II and III respectively, at 12 hours was 3, 3 and 12 cases in group I, II and III respectively and at 24 hours was 2, 2 and 12 cases in group I, II and III respectively.
Lignocaine spray decreased incidence of cough at tracheal extubation in surgeries of $<2 \mathrm{~h}$. Medicated lozenges of licorice had efficacy of decreasing POST in smokers for surgery under GA of more than $1 \mathrm{~h}$. Recently, siccoral and strefen have been found to be effective in relieving POST in the early hours following extubation. ${ }^{[12]}$

The shortcoming of the study is small sample size.

\section{Conclusion}

Authors found that POST can be equally managed with nebulisation with ketamine preoperatively and application of betamethasone gel over endotracheal tube cuff.

\section{References}

1. Al-Qahtani AS, Messahel FM. Quality improvement in anesthetic practice- incidence of sore throat after using small tracheal tube. Middle East J Anesthesiol. 2005;18(1):179-83.

2. Ogata J, Minami K, Horishita T, Shiraishi M, Okamoto T, Terada T, et al. Gargling with Sodium Azulene Sulfonate Reduces the Postoperative Sore Throat After Intubation of the Trachea. Anesth Analg. 2005;101(1):290-293. Available from: https://doi.org/10.1213/01.ane.0000156565.60082.7c.

3. Thomas S, Beevi S. Dexamethasone reduces the severity of postoperative sore throat. Can J Anaesth. 2007;54(11):897901. Available from: https://doi.org/10.1007/bf03026793.

4. Kazami A, Afshiniamini. The effect of Betamethasone gel in reducing sore throat, cough, and hoarseness after laryngo-tracheal intubation. Middle East J Anaesthesiol. 2007;19(1):197-204.

5. Sumathi PA, Shenoy T, Ambareesha M, Krishna HM. Controlled comparison between betamethasone gel and lidocaine jelly applied over tracheal tube to reduce postoperative sore throat, cough, and hoarseness of voice. $\mathrm{Br} J$ Anaesth. 2008;100(2):215-218. Available from: https://doi.org/10. 1093/bja/aem341.

6. Canbay O, Celebi N, Sahin A, Celiker V, Ozgen S, Aypar U. Ketamine gargle for attenuating postoperative sore throat. Br J Anaesth. 2008;100(4):490-493. Available from: https: //doi.org/10.1093/bja/aen023.

7. Tazeh-kand NF, Eslami B, Mohammadian K. Inhaled Fluticasone Propionate Reduces Postoperative Sore Throat, Cough, and Hoarseness. Anesth Analg . 2010;111(4):895-898. Available from: https://doi.org/10.1213/ane.0b013e3181c8a5a2.

8. Damle SG, Gandhi M, Laheri V. Comparison of oral ketamine and oral midazolam as sedative agents in pediatric dentistry. J Indian Soc Pedod Prev Dent. 2008;26(3):97-101. Available from: https://dx.doi.org/10.4103/0970-4388.43186.

9. Khatavkar S, Bakhshi R. Comparison of nasal Midazolam with Ketamine versus nasal Midazolam as a premedication in children. Saudi J Anaesth. 2014;8(1):17-21. Available from: https://dx.doi.org/10.4103/1658-354X.125904.

10. Kajal K, Dharmu D, Bhukkal I, Yaddanapudi S, Soni SL, Kumar M, et al. Comparison of Three Different Methods of 
Attenuating Postoperative Sore Throat, Cough, and Hoarseness of Voice in Patients Undergoing Tracheal Intubation. Anesth Essays Res. 2019;13(3):572-576. Available from: https://dx. doi.org/10.4103/aer.AER_61_19.

11. Ahuja V, Mitra S, Sarna R. Nebulized ketamine decreases incidence and severity of post-operative sore throat. Indian J Anaesth. 2015;59(1):37-42. Available from: https://doi.org/10. 4103/0019-5049.149448.

12. Jain S, Bendwal HP, Gohiya S, Alwani N, Pancholi S, Romday R. Comparison of nebulized ketamine and ketamine with clonidine in postoperative sore throat. Int Surg J. 2017;4(5):1579. Available from: https://dx.doi.org/10.18203/ 2349-2902.isj20171515.

Copyright: (C) the author(s), 2020. It is an open-access article distributed under the terms of the Creative Commons Attribution License (CC BY 4.0), which permits authors to retain ownership of the copyright for their content, and allow anyone to download, reuse, reprint, modify, distribute and/or copy the content as long as the original authors and source are cited.

How to cite this article: Sankardevar SA, Arjun NR, Hegde UB. Betamethasone Versus Ketamine for Attenuation of POST in Patients Undergoing Surgeries Under GA with Endotracheal Intubation- A Clinical Study. Acad. Anesthesiol. Int. 2020;5(2): 26-29.

DOI: dx.doi.org/10.21276/aan.2020.5.2.5

Source of Support: Nil, Conflict of Interest: None declared. 